\title{
Mewujudkan Sistem Peradilan Pidana Terpadu Melalui Case Management System (Studi di Kejaksaan Negeri Kota Bogor)
}

\section{E. Agus Suryadi ${ }^{1}$ dan H. Supardi ${ }^{2}$}

${ }^{1}$ Fakultas Hukum, UPN Veteran Jakarta, Jakarta, Indonesia agus.70suryadi@gmail.com

${ }^{2}$ Fakultas Hukum, UPN Veteran Jakarta, Jakarta, Indonesia supardi@upnvj.ac.id

Article history:

Received: 30 November 2020 | Last Revision: 8 February 2021 | Accepted: 20 February 2021

\begin{abstract}
This research is motivated by the efforts of the Bogor Public Prosecutor's Office (Bogor PPO) in implementing information technology innovation in handling narcotics and psychotropic cases through the Case Management System (CMS) in order to realize good and professional governance, reduce abuse of authority, and discipline case administration since its issuance. Notification of Commencement of Investigation (SPDP) until execution. The problems examined in this paper are about how the application and effectiveness of CMS in narcotics and psychotropic cases at the Bogor PPO, and the obstacles faced. The method that used in this research is Social Legal Research with qualitative descriptive method. The sources of data in this study were obtained through library and field research by distributing questionnaires and interview. Based on the research results, the data input process for handling cases of narcotics and psychotropic crimes is in accordance with established standard procedures. The Bogor PPO has also implemented an Integrated Case Management System-Information Technology, in order to increase the efficiency and effectiveness of case handling. Constraints faced in practice are a lack of operator personnel and a lack of understanding of CMS functions. In conclusion, the Bogor PPO has made efforts to optimize the use of information technology in the implementation of law enforcement tasks, in order to realize an Integrated Criminal Justice System through CMS, but still requires increasing the expertise of its employees through education and training in the field of information technology continuously.
\end{abstract}

Keywords: prosecutor's office, case management system, integrated criminal justice system. 


\begin{abstract}
Abstrak
Penelitian ini dilatarbelakangi oleh upaya Kejaksaan Negeri Bogor (Kejari Bogor) dalam menerapkan teknologi informasi dalam penanganan perkara narkotika dan psikotropika melalui Case Management System (CMS) guna mewujudkan tata kelola pemerintahan yang baik dan professional, mengurangi penyalahgunaan wewenang dan disiplin administrasi perkara sejak diterbitkan Surat Pemberitahuan Dimulainya Penyidikan (SPDP) sampai dengan eksekusi. Permasalahan yang dikaji dalam penelitian ini adalah tentang bagaimana penerapan dan efektivitas CMS pada kasus narkotika dan psikotropika di Kejari Bogor serta kendala yang dihadapi. Metode yang digunakan dalam penelitian ini adalah yuridis empiris dengan metode deskriptif kualitatif. Sumber data dalam penelitian ini diperoleh melalui studi kepustakaan dan penelitian lapangan dengan cara melakukan penyebaran kuesioner dan wawancara. Berdasarkan hasil penelitian, proses input data penanganan kasus narkotika dan psikotropika sesuai dengan prosedur standard yang ditetapkan. Kejari Bogor juga telah menerapakan Sistem Manajemen Perkara-Teknologi Informasi Terpadu guna meningkatkan efisiensi dan efektifitas penanganan perkara. Kendala yang dihadapi dalam praktiknya adalah kuranya personil operator serta kurangnya pemahaman mengenai fungsi CMS. Kesimpulannya, Kejari Bogor telah melakukan upaya optimalisasi pemanfaatan teknologi informasi pada pelaksanaan tugas penegakan hukum dalam rangka mewujudkan Sistem Peradilan Pidana Terpadu melalui CMS, namun hal ini tetap membutuhkan peningkatkan keahlian karyawannya melalui pendidikan dan pelatihan dibidang teknologi informasi secara berkelanjutan.
\end{abstract}

Kata Kunci: Kejaksaan, Sistem Manajemen Perkara, Peradilan Pidana Terintegrasi.

\title{
A. PENDAHULUAN
}

Penggunaan aplikasi berbasis teknologi oleh institusi penegak hukum merupakan bagian dari transparansi dan akuntabilitas guna meningkatkan pelayanan dan kepercayaan masyarakat (Filgueiras, 2015). Kejaksaan Republik Indonesia telah melakukan perubahan Reformasi Birokrasi yang merupakan salah satu langkah awal untuk melakukan penataan terhadap sistem penyelenggaraan pemerintahan yang baik, efektif dan efisien, sehingga dapat melayani masyarakat secara cepat, tepat, dan profesional. Dalam praktik, banyak kendala yang dihadapi oleh Kejaksaan, diantaranya adalah penyalahgunaan wewenang, 
praktik korupsi, kolusi dan nepotisme, serta lemahnya pengawasan, sehingga diperlukan sebuah terobosan dengan memanfaatkan teknologi guna menertibkan administrasi perkara sejak dikeluarkannya Surat Pemberitahuan Dimulainya Penyidikan (SPDP) dari Penyidik Polri, tahap Pra Penuntutan, tahap Penuntutan, sampai tahap Eksekusi.

Mochtar Kusumaatmadja berpendapat bahwa hukum memerlukan kekuasaan bagi pelaksanaannya, sebaliknya kekuasaan itu sendiri ditentukan batas-batasnya oleh hukum karena hukum tanpa kekuasaan adalah angan-angan, dan kekuasaan tanpa hukum adalah kelaliman (Kusumaatmadja, 1976). Pendapat ini bermakna bahwa penegak hukum tidak boleh bertindak sewenang-wenang dalam melaksanakan tugasnya, karena kewenangan yang dimilikinya pada kenyataannya merupakan kewenangan formal yang diatur oleh ketentuan-ketentuan hukum. Pemeriksaan perkara di pengadilan yang dilakukan secara terbuka untuk umum dimaksudkan untuk menjamin objektivitas kekuasaan kehakiman (Cardozo, 1991), karena jika tidak terpenuhi dapat menyebabkan putusan batal demi hukum.

Salah satu isu utama dalam penegakan hukum di Indonesia adalah tentang penumpukan perkara yang belum terselesaikan, oleh sebab itu perlu dipikirkan perubahan yang komprehensif terhadap sistem peradilan di Indonesia (Rahardjo, 1991). Dengan adanya proses peradilan yang terbuka untuk umum dan guna mengurangi adanya penumpukan perkara yang tidak terselesaikan, diperlukan adanya pembaharuan dalam sistem pelaksanaan persidangan suatu perkara (Atmasasmita, 2010). Hal ini diwujudkan dalam suatu sistem peradilan yang saling terintegrasi dan saling terpadu antara lembaga penegakan hukum yang satu dengan lembaga penegakan hukum lainnya, yakni Kepolisian, Kejaksaan, Pengadilan, Lembaga Pemasyarakatan, dan Penasihat Hukum (pengacara) (Harahap, 2004), dengan menerapkan kemajuan teknologi informasi seperti 
sekarang ini, sehingga diharapkan mengembalikan dan memulihkan kembali kepercayaan masyarakat pencari keadilan terhadap sistem peradilan dan meningkatkan kredibilitas dan akuntabilitas lembaga penegakan hukum.

Proses peradilan yang terbuka untuk umum dengan harapan dapat memulihkan kembali kepercayaan masyarakat pencari keadilan, meningkatkan kredibilitas dan akuntabilitas penegakan hukum, tidaklah dapat terlepas dari kesadaran penegak hukum dan masyarakat hukum itu sendiri. Salah satu fungsi hukum untuk mencapai tujuan asasinya yang didukung oleh kesadaran hukum masyarakat dalam pembangunan nasional, sebagaimana dikatakan Muchtar Kusumaatmadja, adalah hukum merupakan sarana pembaruan masyarakat atau sebagai sarana pembangunan (Kusumaatmadja, 2002). Oleh karena itu, apabila hukum telah berfungsi secara efektif di dalam masyarakat, maka hukum dapat mencapai tujuannya yang menimbulkan efek keadilan sekaligus bermanfaat secara luas bagi masyarakat. Bahkan, dapat mempercepat pelaksanaan pembangunan. Ada anekdot yang pernah hangat dalam masyarakat bahwa hukum dibuat untuk dilanggar. Pendapat ini sebenarnya keliru dan tidak menyadari bahwa dimana ada masyarakat disitu ada hukum (ubi societis ubi ius), bahkan hukum itu lahir dan berkembang di dalam masyarakat. Apabila dikatakan bahwa hukum itu dibuat untuk dilanggar maka sama saja dengan mengatakan bahwa masyarakat itu ada untuk dihancurkan, diobrak-abrik, dan dikacaukan (Mas, 2003).

Ada dua fungsi yang dapat dijalankan oleh hukum di dalam masyarakat, yaitu sebagai sarana kontrol sosial (Vago, 2016) dan alat rekayasa sosial (Rasjidi, 1990). Sebagai sarana kontrol sosial maka hukum bertugas untuk menjaga agar masyarakat tetap berada di dalam pola-pola tingkah laku yang telah diterima olehnya. Di dalam peranannya yang demikian ini hukum hanya mempertahankan saja apa yang telah menjadi sesuatu 
yang tetap dan diterima di dalam masyarakat atau hukum sebagai penjaga status quo. Tetapi diluar itu, hukum masih dapat menjalankan fungsinya yang lain yaitu dengan tujuan untuk mengadakan perubahan-perubahan di dalam masyarakat (Rahardjo, 1980). Fungsi hukum sebagai sarana social control bertujuan untuk memberikan suatu batasan tingkah laku masyarakat yang menyimpang dan akibat yang harus diterima dari penyimpangan itu. Penggunaan hukum sebagai sarana social control dapat berarti hukum mengontrol tingkah laku masyarakat, maksudnya hukum berfungsi memberikan suatu batasan tingkah laku warga masyarakat yang dianggap menyimpang dari aturan hukum, serta apa akibat (sanksi) dari penyimpangan itu (Rahardjo, 1980).

Hukum merupakan salah satu alat negara dalam menjaga cita-cita nasionalnya. Karena negara pada hakikatnya adalah tatanan politik suatu masyarakat, maka cita-cita hukum suatu negara idealnya merupakan hasil dari cita-cita politiknya, oleh karena itu hukum yang berlaku tentunya memuat cita-cita politik penguasa (pemerintahan). Salah satu kebijakan politik hukum pemerintahan Presiden Joko Widodo dalam pembangunan hukum dan HAM di Indonesia adalah dengan mendorong pengembangan Sistem Penanganan Perkara Terpadu berbasis Teknologi Informasi (SPPT-TI). SPPT-TI tersebut diarahkan pada terwujudnya keterpaduan antar sub sistem yang ada di dalam sistem peradilan pidana, sebagai inovasi dalam rangka mempercepat dan mempermudah proses penanganan perkara yang transparan dan akuntabel. SPPT-TI merupakan salah satu fokus kebijakan Pemerintah yang ditindaklanjuti dengan dikeluarkannya Peraturan Presiden Nomor 54 Tahun 2018 tentang Strategi Nasional Pencegahan Korupsi.

Guna mendukung kebijakan pemerintah tersebut, serta mengurangi lemahnya pengawasan terhadap akuntabilitas kinerja pegawai serta penataan terhadap sistem penyelenggaraan pemerintahan yang baik, efektif dan efisien, sehingga dapat melayani 
masyarakat secara cepat, tepat, dan profesional guna meningkatkan kepercayaan publik dengan menerapkan sistem peradilan pidana secara terpadu dan terintegrasi antar institusi penegak hukum, Jaksa Agung Republik Indonesia telah menerbitkan Instruksi Jaksa Agung Nomor 3 Tahun 2020 (Insja No. 3 Tahun 2020) tentang Penggunaan Aplikasi Sistem Manajemen Perkara (Case Management System) sehingga adanya upaya yang “memaksa" para Jaksa yang menangani perkara untuk melakukan input data penanganan perkara dan melengkapi administrasi persuratan pada setiap tahapan penanganan perkara yang ditanganinya, sehingga terdapat peningkatan kinerja dan pelayanan publik yang dipenuhi oleh institusi Kejaksaan terhadap masyarakat yang mencari keadilan.

Sejak diluncurkan sejak tahun 2018 sampai dengan akhir Desember 2019, implementasi aplikasi CMS tindak pidana umum dan khusus telah dilakukan di 31 Kejaksaan Tinggi dan 429 Kejaksaan Negeri, dan salah satunya adalah Kejaksaan Negeri Kota Bogor (Kejari Bogor). Yang menarik, berdasarkan observasi penulis menemukan ada ketidaksinkronan data antara SPDP yang terdapat pada buku agenda/manual (konvensional), pada aplikasi Simkari dan SPDP pada aplikasi CMS di Kejari Bogor. Sebagai Kejaksaan Negeri Tipe A, menurut penulis perbedaan data tersebut terlalu mencolok dan diluar batas toleransi kesalahan (margin of error), sebagaimana disajikan berikut ini: 


\section{Tabel 1}

Data Perkara Pidana Umum, Aplikasi Simkari dan Aplikasi CMS

\section{Konvensional}

Tahun

(Buku Agenda/Manual)

\section{Simkari CMS Simkari}

\begin{tabular}{llcc}
\hline 2018 & 463 & 423 & 5 \\
\hline 2019 & 574 & 489 & 433
\end{tabular}

Sumber: Pusat Data Statistik Kriminal dan Teknologi Informasi, 2019.

Dari tabel tersebut, dapat diketahui terjadi perbedaan yang signifikan antara data SPDP yang terdapat pada buku agenda/manual (konvensional), pada aplikasi Simkari dan data SPDP pada aplikasi CMS. Ketidaksinkronan data ini dapat menimbulkan praduga adanya "praktik penyimpangan" oleh Jaksa dalam menangani perkara yang dapat berakibat pada status perkembangan penanganan perkara, perencanaan kerja dan proses pengambilan keputusan tidak dapat dilakukan secara cepat efektif, dan efisien. SPPT-TI merupakan salah satu fokus kebijakan Pemerintah yang diharapkan dapat menjamin adanya ketersediaan, ketepatan, dan keakuratan serta kecepatan dalam memperoleh dan memproses data dalam rangka penegakan hukum yang berkualitas. Sebagai salah satu Kejaksaan Negeri Tipe A, Kejari Bogor seharunya dapat mengimplementasikan CMS sebagai salah satu bentuk SPPT-TI, sehingga dapat dijadikan acuan atau contoh Kejaksaan Negeri lainnya di wilayah Kejaksaan Tinggi Jawa Barat.

Menurut Riyanto Setiadi (Setiadi, 2020) di Kejari Bogor, jumlah perkara terbanyak adalah perkara tindak pidana narkotika dan psikotropika, dimana pada tahun 2018 berjumlah 98 perkara, dan 44 perkara pada tahun 2019. Ketidaksinkronan data tersebut diduga berasal dari perkara-perkara tindak pidana narkotika dan psikotropika yang ditangani oleh Kejari Bogor. Mengingat banyaknya jumlah perkara yang tidak sebanding 
dengan jumlah Jaksa yang bertugas di Kejari Bogor, kemungkinan para Jaksa yang bertugas menangani perkara tersebut belum melakukan input data ke Simkari dan CMS karena besarnya beban kerja menangani perkara. Oleh karena itu, dalam penelitian ini penulis akan memfokuskan kepada CMS pada perkara tindak pidana narkotika dan psikotropika yang ditangani oleh Kejari Bogor.

Berdasarkan uraian tersebut, maka tulisan ini akan membahas 3 (tiga) persoalan, yakni mengenai bagaimana penerapan CMS dalam proses input data penanganan perkara tindak pidana narkotika dan psikotropika di Kejari Bogor, efektivitas dan peranan Kejari Bogor dalam mewujudkan sistem peradilan pidana terpadu melalui CMS khususnya dalam penanganan perkara tindak pidana narkotika dan psikotropika, dan kendala yang dihadapi Kejari Bogor dalam penerapan sistem CMS terkait penanganan perkara tindak pidana narkotika serta cara mengatasinya.

Penelitian mengenai sistem manajemen perkara pernah dilakukan oleh Asvera Primadona dalam tesis yang berjudul "Manajemen Perkara Tindak Pidana Umum di Kejaksaan Suatu Telaah Kritis Guna Peningkatan Kinerja Kejaksaan”. Penelitian ini berbeda dengan penelitian tersebut karena fokus penelitian ini menganalisis mengenai penerapan CMS dalam proses input data penanganan, sedangkan penelitian sebelumnya hanya membahas mengenai manajemen perkara dengan masih dengan sistem manual atau konvensional (pencatatan tertulis dalam buku register perkara).

\section{B. METODE PENELITIAN}

Penelitian ini merupakan penelitian yuridis empiris dengan menggunakan metode deskriptif kualitatif untuk menggambarkan alur penerapan aplikasi CMS di Kejari Bogor, efektivitas dan peranan Kejari Bogor dalam mewujudkan Sistem Peradilan Pidana 
Terpadu dengan adanya penerapan CMS itu sendiri serta kendala-kendala yang dihadapi dalam penerapan aplikasi CMS dan cara mengatasinya. Sumber data dalam penelitian ini yaitu dengan studi kepustakaan, dan penelitian lapangan dengan melakukan penyebaran kuesioner dan wawancara kepada para Jaksa yang menangani perkara tindak pidana narkotika dan psikotropika dan operator Simkari-CMS di Kejari Bogor. Analisis kemudian dilakukan dengan mengklasifikasikan bahan hukum sesuai dengan jenisnya, yaitu bahan hukum primer, bahan hukum sekunder, dan bahan hukum tersier; menganalisis bahan hukum sesuai dengan permasalahan dalam hal ini mengenai peran Kejari Bogor dalam mewujudkan Sistem Peradilan Pidana Terpadu melalui CMS (studi terhadap perkara tindak pidana narkotika dan psikotropika); selanjutnya menyusun kesimpulan sebagai upaya untuk memberikan gambaran objektif dan aktual dari permasalahan berkenaan dengan peran Kejari Bogor dalam mewujudkan Sistem Peradilan Pidana Terpadu melalui CMS tersebut.

\section{HASIL DAN PEMBAHASAN}

Hukum haruslah dapat merespons segala seluk beluk kehidupan sosial yang melingkupinya agar tidak tertinggal dari perkembangan masyarakat. Oleh karena itu peranan hukum sangat penting dalam menghadapi permasalahan sosial yang akan muncul nantinya. Dalam konteks demikian, hukum tidak hanya dipahami secara yuridis normatif saja, tetapi juga harus dipahami secara deskriptif melalui pendekatan ilmu-ilmu sosial. Studi hukum non-yuridis normatif telah menunjukkan bahwa hukum bukan lagi sebagai lembaga yang otonom melainkan sebagai suatu proses sosial dengan memanfaatkan hasil dari karya para ahli ilmu sosial dalam menghadapi masalahnya. Tak dapat dipungkiri perkembangan masyarakat semakin maju dan kompleks. Oleh karena itu, diperlukan 
aturan hukum yang sejalan dengan hal tersebut. Dengan demikian, hukum memegang peranan yang sangat penting sebagai kerangka kehidupan sosial masyarakat modern (Abdullah, 2014).

Penegakan hukum terletak pada kegiatan menyelaraskan hubungan nilai-nilai yang terjabarkan di dalam kaidah-kaidah yang tetap dan melaksanakan sikap tindak sebagai rangkaian penjabaran nilai tahap akhir untuk menciptakan, memelihara, dan tentu saja dalam proses penegakan hukum diharapkan hasil yang optimal, sehingga aturan-aturan hukum pidana berfungsi secara efektif untuk mencegah seseorang melakukan perbuatanperbuatan yang dilarang, dan kalau ternyata aturan-aturan itu dilanggar, aparat penegak hukum dapat menjalankan fungsinya secara efektif pula (Abdullah, 2014). Upaya untuk mewujudkan penegakan hukum yang optimal ini dilakukan dengan berbagai macam cara dan pendekatan. Salah satu bentuknya yakni dengan penerapan sistem peradilan pidana secara terpadu dan terintegrasi antara aparat penegakan hukum antara lain kepolisian, kejaksaan, pengadilan dan advokat.

Penegakan hukum mencakup pengertian mengenai institusi penegak hukum dan aparat (orangnya) penegak hukum dimulai dari saksi, polisi, penasihat hukum, jaksa, hakim, dan petugas sipir pada lembaga pemasyarakatan dengan mencakup pihak-pihak yang bersangkutan dengan tugas atau perannya terkait dengan pelaporan atau pengaduan, penyelidikan, penyidikan, penuntutan, pembuktian, penjatuhan vonis dan pemberian sanksi serta upaya pemasyarakatan kembali (resosialisasi) terpidana (Abdullah, 2014). Lembaga penegakan hukum saat ini telah menerapkan sistem peradilan pidana secara terpadu dan terintegrasi antara satu lembaga penegakan hukum dengan lembaga penegakan hukum lainnya sebagai wujud nyata dalam mewujudkan efisiensi dalam proses peradilan yang sederhana. Berkenaan dengan penyederhanaan proses peradilan, 
apabila dihubungkan dengan ajaran Friedman tentang legal system (sistem hukum) meliputi tiga unsur yakni struktur hukum, substansi hukum, dan budaya hukum dapat dijadikan ukuran efektivitas keberhasilan penerapan sistem peradilan satu atap di Indonesia yang sampai saat ini masih banyak kelemahan (Situmorang, 2009).

Peradilan yang efisien adalah sistem peradilan yang sederhana, cepat, dan berbiaya rendah. Ini menyiratkan proses peradilan yang lugas, programnya jelas, mudah dipahami dan biayanya terjangkau bahkan hingga ke tingkat akar rumput. Namun dalam implementasinya, prinsip ini masih sulit dilakukan. Banyak perkara yang diproses dalam waktu yang cukup lama dan tidak sederhana sama sekali, karena banyaknya tingkatan peradilan, dan biaya yang tidak bisa dikatakan ringan, terutama jika menyangkut tingkat kasasi (Hairi, 2011).

Integrasi artinya memadukan, menyatukan, menggabungkan, dan menggabungkan sesuatu yang berbeda menjadi satu kesatuan yang utuh, yang berbeda dari bentuk aslinya menjadi sesuatu yang baru. Sedangkan secara terminologi, dalam ilmu-ilmu sosial, sebagaimana dalam kamus sosiologi integrasi, diartikan bahwa salah satu masalah sosial abadi masyarakat adalah bagaimana berbagai elemen masyarakat menjaga persatuan, bagaimana mereka berintegrasi satu dengan yang lainnya. Dalam Kamus Sosiologi Soerjono Soekanto, integrasi berarti mengendalikan konflik dan penyimpangan dalam suatu sistem sosial dan menyatu dari unsur-unsur tertentu. Sedangkan integrasi budaya berarti derajat ketergantungan fungsional dari unsur-unsur budaya (Rahardjo, 1983).

Fungsi ideal pengadilan sebagai lembaga penegakan hukum yang bertugas menegakkan hukum dan keadilan saat ini sedang mengalami keterpurukan, akibat fabrikasi, diskriminasi dan ketidakadilan akibat korupsi peradilan, yang populer disebut mafia peradilan (Alkostar, 2002). Mafia peradilan yang merupakan bentuk kegagalan 
peradilan sebagai sarana mencari keadilan, telah menjadi pola penyimpangan dalam proses peradilan pidana (Widodo, 2012). Praktik mafia peradilan merupakan perbuatan melawan hukum yang merusak independensi dan imparsialitas pengadilan, karena rekayasa hukum yang dilakukan oleh sindikat mafia peradilan melanggar asas proses hukum dalam proses peradilan pidana. Praktik mafia peradilan telah mengakibatkan diskriminasi terhadap pencari keadilan berdasarkan pertimbangan rasionalitaspragmatisme, bertumpu pada kekuatan "uang dan kekuasaan”, mengabaikan prinsip penegakan hukum pidana yang adil (Widodo, 2012).

Proses peradilan pidana dijalankan berdasarkan pertimbangan "transaksional" antar para pihak yang mempunyai kekuatan ekonomi dengan kekuasaan publik yaitu penegak hukum, menghasilkan penegakan hukum pidana yang tidak adil dan diskriminatif. Praktik mafia peradilan menjadi catatan buruk bagi institusi penegakan hukum karena merusak integritas dalam penegakan hukum bagi masyarakat (Syamsudin, 2008). Apabila dalam proses penegakan hukum sudah rusak dan terkontaminasi dengan kepentingan materi dan kekuasaan, maka putusan tidak berpihak pada keadilan yang dapat menyebabkan masyarakat tidak percaya terhadap kredibilitas lembaga penegakan hukum yang pada akhirnya dapat mengakibatkan proses main hakim sendiri (eigenrichting) atau penghinaan terhadap pengadilan (obstruction of justice) (Mardin, 2007).

Penegakan hukum pidana terdistorsi rasionalitas transaksi ekonomi, sehingga proses peradilan pidana tidak lebih dari lembaga yang berusaha mencari pembenaran (justification), yang seharusnya mencari kebenaran (truth) dan keadilan (justice). Praktik mafia peradilan semakin kreatif dalam membuat pembenaran proses hukum yakni dengan membentuk tim lobi sebagai bagian strategi pembelaan perkara tim pengacara untuk merekayasa proses hukum. Pembelaan perkara pidana tidak lagi dibangun atas dasar 
argumentasi hukum yang logis dan pendekatan ke berbagai pihak yaitu penyidik, penuntut umum atau hakim untuk memenangkan perkara, meringankan pidana atau membebaskan terdakwa kliennya. Bahkan kekuatan mafia peradilan juga telah merambah ke komunitas akademik, dengan cara mengatur keterangan hukum saksi ahli dalam pembuktian memberikan keterangan di muka pengadilan (Widodo, 2012). Untuk memperbaiki keadaan ini, dibutuhkan sebuah inovasi yang mengandung transparansi dan akuntabilitas penanganan suatu perkara oleh penegak hukum, dimana salah satunya adalah dengan memanfaat teknologi yakni CMS.

\section{Penerapan CMS dalam Penanganan Perkara di Kejari Bogor}

Penerapan sistem manajemen penanganan perkara berbasis teknologi informasi di Kejaksaan Republik Indonesia tidak terlepas dari Standar Operasional Prosedur dalam penanganan perkara sebagaimana diatur dalam Keputusan Jaksa Agung Republik Indonesia Nomor: KEP-24/E/Ejp/12/2019 tanggal 02 Desember 2019 tentang Standar Operasional Prosedur Penanganan Perkara Tindak Pidana Umum. Menurut Herbeth Pesta Hutapea (Hutapea, 2020), Standar Operasional Prosedur (SOP) penanganan perkara tindak pidana umum dibuat sebagai pedoman acuan kerja yang memiliki kekuatan hukum sehingga dapat menjamin keseragaman, transparansi, akuntabilitas, efektivitas dan efisiensi serta tertib dalam proses penanganan perkara bidang tindak pidana umum guna menegakkan hukum dan keadilan pada setiap satuan kerja di Kejaksaan, termasuk juga di Kejari Bogor. Standar operasional prosedur penanganan perkara tindak pidana umum sebagai pedoman dalam pelaksanaan tugas dan fungsi Kejaksaan dalam menegakkan hukum khususnya Kejari Bogor, menjadi suatu pola yang terpadu dalam pelaksanaannya. 
P-ISSN: 2656-534X, E-ISSN: 2656-5358

Jurnal Suara Hukum, Vol. 3, No. 1, Maret 2021

Berdasarkan Instruksi Jaksa Agung Nomor 3 Tahun 2020, Sistem Manajemen Penanganan Perkara (Case Management System/CMS) merupakan sistem pengelolaan administrasi perkara berbasis bisnis proses penanganan perkara dan sumber data atau informasi yang dibangun oleh Kejaksaan Republik Indonesia. Kejari Bogor dalam pelaksanaan tugas dan fungsinya telah menerapkan sistem penanganan perkara berbasis teknologi informasi dimana setiap tahapan penanganan perkara narkotika dan psikotropika dan tindak pidana umum lainnya dilakukan penginputan data penanganan perkara dimulai dari tahap SPDP dari Penyidik sampai dengan tahap eksekusi (Hutapea, 2020). Berdasarkan wawancara dengan Operator Simkari pada Kejaksaan Negeri Bogor, Lia Yulianti (Yulianti, 2020), adapun alur penerapan dalam proses input data penanganan perkara pada sistem manajemen penanganan perkara (Case Management System) dimulai pada saat penerimaan SPDP, tahap Pra Penuntutan (Pratut), tahap Penuntutan (Tut), sampai dengan tahap Eksekusi (Eksekusi) pada Kejari Bogor adalah sebagai berikut: 


\section{Gambar 1}

Pola Alur Input Data Sistem Manajemen Penanganan Perkara (Case Management System) pada Kejari Bogor

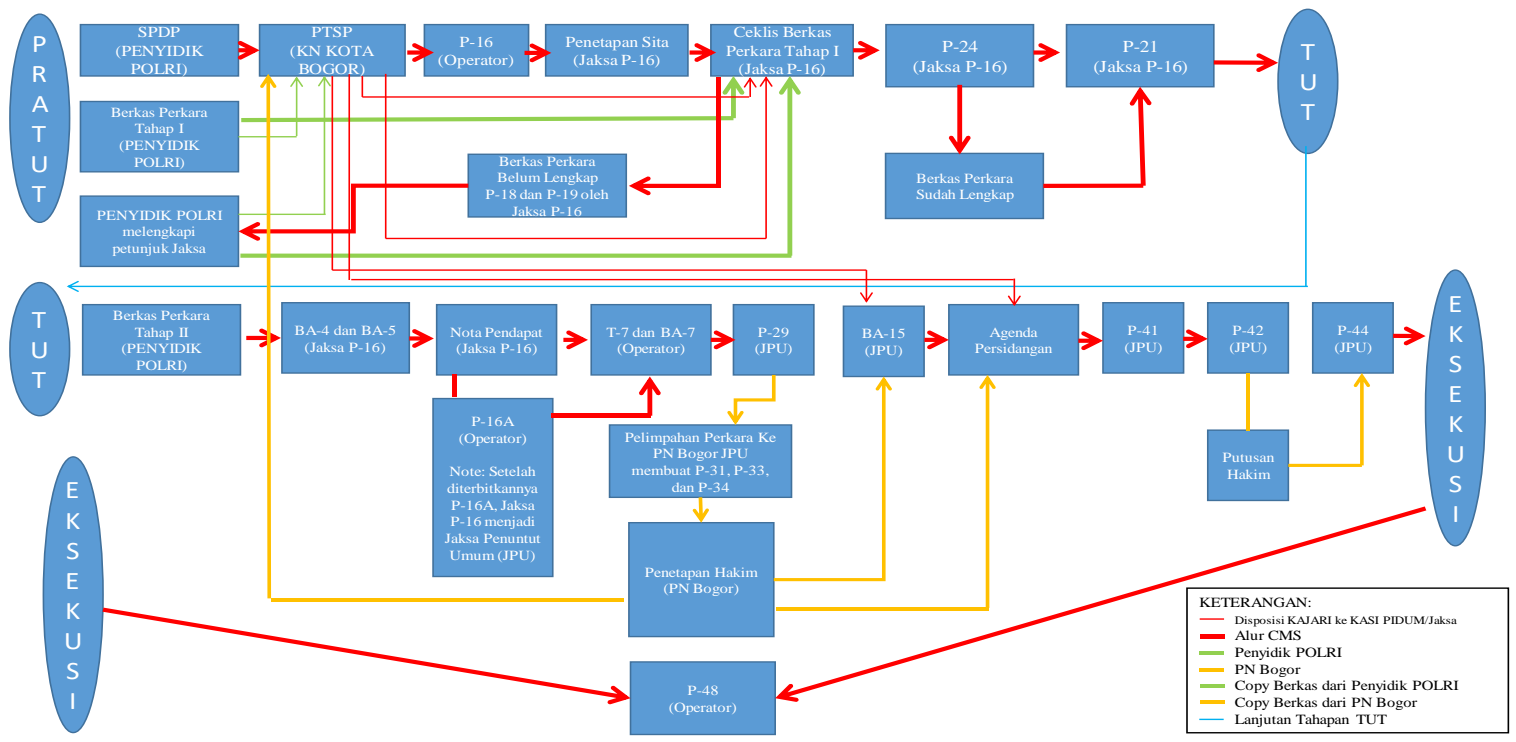

Sumber: Pusat Data Pusat Data, Statistik Kriminal dan Teknologi Informasi Kejaksaan Agung.

Sistem Manajemen Penanganan Perkara (Case Management System/CMS) merupakan sistem pengelolaan administrasi perkara berbasis bisnis proses penanganan perkara dan sumber data atau informasi yang dibangun oleh Kejaksaan Republik Indonesia yang sudah disesuaikan dengan Standar Operasional Prosedur administrasi penanganan perkara tindak pidana umum dalam 4 (empat) kelompok penanganan perkara yakni perkara Keamanan Negara dan Ketertiban Umum (Kamnegtibum), perkara Orang dan Harta Benda (Oharda), perkara Narkotika dan perkara Terorisme yang bentuk dan alur administrasi penanganan perkaranya sudah sesuai dengan Keputusan Jaksa Agung Republik Indonesia Nomor: KEP-24/E/Ejp/12/2019 tanggal 02 Desember 2019 tentang Standar Operasional Prosedur Penanganan Perkara Tindak Pidana Umum yang dimasukkan ke dalam template aplikasi CMS. Kemudian, dipertegas lagi dengan diberlakukannya Instruksi Jaksa Agung Nomor 3 Tahun 2020 tentang Penggunaan 
P-ISSN: 2656-534X, E-ISSN: 2656-5358

Jurnal Suara Hukum, Vol. 3, No. 1, Maret 2021

Aplikasi Sistem Manajemen Penanganan Perkara (Case Management System/CMS) (Yulianti, 2020).

\section{Efektivitas dan Peranan Kejari Bogor dalam Mewujudkan Sistem Peradilan Pidana Terpadu Melalui CMS}

Sistem penegakan hukum pidana pada dasarnya merupakan sistem kekuasaan/kewenangan menegakkan hukum. Kekuasaan/kewenangan menegakkan hukum ini dapat diidentikkan pula dengan istilah "Kekuasaan kehakiman”. Bertolak dari pemikiran tersebut, maka kekuasaan kehakiman di bidang hukum pidana terdiri dari kekuasaan penyidikan (Badan Penyidikan), Kekuasaan Penuntutan (Badan Penuntutan), Kekuasaan Mengadili (Badan Pengadilan), dan Kekuasaan Pelaksana Pidana (Badan Eksekusi) yang merupakan satu kesatuan sistem penegakan hukum pidana yang integral atau sering dikenal dengan istilah Sistem Peradilan Pidana Terpadu (integrated criminal justice system).

Kemandirian (independensi) sistem peradilan pidana mengandung arti kebebasan, kemandirian, kemandirian atau tidak berada di bawah kendali lembaga/kekuasaan lain. Untuk membentuk Sistem Peradilan Pidana Terpadu, gagasan "kekuasaan kehakiman" yang mandiri harus diwujudkan secara utuh, sehingga harus terwujud dalam keseluruhan proses penegakan hukum pidana. Artinya, keseluruhan kekuasaan kehakiman di bidang hukum pidana (kekuasaan penyidikan, penuntutan dan mengadili) harus independen, bebas dan terlepas dari pengaruh kekuasaan pemerintah/eksekutif termasuk seluruh proses dalam pidana. sistem keadilan.

Kejaksaan berdasarkan Undang-undang Nomor 16 Tahun 2004 tentang Kejaksaan Republik Indonesia telah diberikan kewenangan untuk melaksanakan kekuasaan negara 
di bidang penuntutan. Kejaksaan memiliki peran yang sangat penting dalam proses penegakan hukum pidana, karena dapat tidaknya perkara pidana masuk ke Pengadilan adalah tergantung sepenuhnya oleh Kejaksaan (Penuntut Umum). Sehingga, peran yang amat besar inilah harus dibarengi dengan independensi dalam melaksanakan kewenangannya tersebut, karena tanpa independensi dari Kejaksaan maka akan sangat sulit mengharapkan independensi kekuasaan peradilan pidana. Dalam praktik peradilan pidana, meskipun hakim bebas tetap terikat dengan apa yang didakwakan oleh Penuntut Umum. Hakim tidak boleh memutus apa yang tidak didakwakan oleh Penuntut Umum. Dengan diundangkannya Undang-undang Nomor 16 Tahun 2004 tentang Kejaksaan Republik Indonesia, kedudukan Kejaksaan menjadi lebih mantap dalam melaksanakan kewenangannya di bidang Penuntutan.

Pasal 1 Ayat (3) Undang-Undang Dasar Negara Republik Indonesia Tahun 1945 menyebutkan bahwa Negara Indonesia adalah negara hukum. Salah satu syarat untuk dapat dikatakan sebagai suatu negara hukum yaitu di negara itu hanya memiliki satu criminal justice system yang kesemuanya berada dalam tatanan pro-Yustisia, dan secara universal berlaku di Negara manapun. Tidak ada satu negara yang benar-benar sebagai negara hukum membuka kemungkinan keberadaan berbagai jenis institusi ekstra yudisial yang bersifat ad hoc, dan seluruh institusi yang termasuk bagian resmi dari criminal justice system telah memiliki aparat profesional yang telah memperoleh pendidikan khusus, mereka semua adalah sarjana hukum yang bukan sekedar menguasai hukum positif dalam bidang hukum pidana dan hukum acara pidana, melainkan juga memahami dan mendalami asas-asas yang berlaku dalam proses pidana, dari awal sampai akhir (Kejaksaan Negeri RI, 2010). 
Acuan utama operasional Sistem Peradilan Pidana di negara hukum Indonesia, bermuara pada Undang-undang Nomor 8 Tahun 1981 tentang Kitab Undang-Undang Hukum Acara Pidana (KUHAP) yang menganut konsep diferensiasi fungsional (fungsi yang berbeda-beda) diantara komponen penegak hukum yang melaksanakan fungsi yang berkaitan dengan kekuasaan kehakiman, yaitu penyelidikan dan penyidikan; penuntutan; pelaksanaan putusan pengadilan; dan pemberian jasa hukum.

Diferensiasi fungsional ini dapat mengakibatkan praktik penegakan hukum oleh aparat penegak hukum menjadi terkotak-kotak dan bersifat fragmentaris karena tiap-tiap komponen penegak hukum mempunyai persepsi dan pemaknaan yang berbeda. Hal ini berdampak pada sulitnya mewujudkan sistem peradilan pidana yang terpadu dan terintegrasi karena seringnya terjadi benturan kepentingan dan perbedaan penafsiran diantara komponen penegak hukum sehingga produk-produk badan peradilan belum dapat memenuhi harapan masyarakat pencari keadilan. Di Indonesia, criminal justice system terdiri dari Kepolisian, Advokat, Kejaksaan dan Pengadilan yang berpuncak pada Mahkamah Agung serta berakhir pada Lembaga Pemasyarakatan yang dalam melaksanakan tugas dan kewenangannya tidak ada intervensi dalam bentuk apapun (Kejaksaan Negeri RI, 2010).

Dari pembahasan tersebut dapat diketahui bahwa Kejaksaan Republik Indonesia dalam hal ini Kejari Bogor, dalam kewenangannya memiliki peranan yang sangat penting dalam mewujudkan Sistem Peradilan Pidana Terpadu Melalui CMS dalam penyajian data dan informasi kepada lembaga penegak hukum lainnya dalam sistem peradilan pidana terpadu berbasis teknologi informasi dengan melakukan penginputan data penanganan perkara pada setiap tahapan penanganan perkara yakni pada tahap Pra Penuntutan, tahap Penuntutan, maupun tahap Eksekusi. Selain itu, Jaksa melaksanakan tugasnya sebagai 
Penyidik, Penuntut Umum dan Eksekutor dalam suatu perkara pidana tidak dapat diintervensi oleh siapapun.

Menurut salah seorang Jaksa yang bertugas di Kejaksaan Negeri Bogor, Heri Joko Saputro (Saputro, 2020), dengan diterapkannya sistem manajemen penanganan perkara yang ada di dalam aplikasi CMS, yang mana secara administratif alur dan riwayat dari penanganan suatu perkara dapat diketahui dengan tertib dan jelas, maka akan berpengaruh besar terhadap keefektifan dalam penanganan suatu perkara. Hal ini dapat diketahui dari tersinkronnya penyajian data dan informasi kepada lembaga penegak hukum lainnya dalam sistem peradilan pidana terpadu berbasis teknologi informasi pada proses penginputan data penanganan perkara, sehingga meminimalisir terjadinya bolak balik penanganan perkara dan menghemat tenaga, waktu dan biaya dalam proses penanganan perkara, sebab dengan diterapkannya CMS misalnya untuk kekurangan data dapat dilengkapi hanya dengan meng-klik data yang akan dilengkapi, kemudian mengunggah kekurangan data dimaksud ke dalam aplikasi CMS. Dengan demikian, dapat dikatakan bahwa penerapan aplikasi CMS cukup efektif dalam memudahkan penanganan suatu perkara dibandingkan dengan pengadministrasian secara konvensional (register perkara).

Peran Kejari Bogor sangat penting dalam mewujudkan sistem peradilan pidana terpadu melalui CMS karena misalnya saja pada tahap pra-penuntutan, sangat menentukan apakah suatu perkara penyidikannya akan dapat ditingkatkan ke tahap Penuntutan, dan pada tahap Penuntutan apakah perkara tersebut dapat ditingkatkan ke tahap persidangan di muka Pengadilan ataukah dihentikan, sehingga dengan diterapkannya CMS, riwayat penanganan perkara tindak pidana dapat ditelusuri dengan lebih cepat, mudah dan efisien tanpa memakan waktu yang lama sehingga Pimpinan 
P-ISSN: 2656-534X, E-ISSN: 2656-5358

Jurnal Suara Hukum, Vol. 3, No. 1, Maret 2021

dalam hal ini Kepala Kejari Bogor dapat segera mengambil keputusan yang cepat, tepat dan efektif.

\section{Kendala Penerapan Sistem CMS}

Kendala yang dihadapi oleh Kejari Bogor dalam hal menerapkan penggunaan aplikasi CMS tidaklah berbeda kondisinya dengan yang dihadapi oleh Kejaksaan Negeri lain pada umumnya. Disini sangat diperlukan kebijakan pimpinan dalam hal ini Kepala Kejari Bogor untuk mengatasi segala kendala yang ada di dalam institusi Kejari Bogor itu sendiri agar proses penanganan perkara dan proses input data penanganan perkara pada aplikasi CMS dapat berjalan dengan tertib dan lancar sehingga berpengaruh pada peningkatan akuntabilitas kinerja Kejari Bogor. Berdasarkan penjelasan Essadendra dan Karyati (Essadendra \& Karyati, 2020), beberapa kendala tersebut diantaranya adalah:

a) Kurangnya Sumber Daya Manusia yang berkompeten

Kurangnya Sumber Daya Manusia yang berkompeten dalam bidang teknologi informasi merupakan permasalahan yang umum terjadi di setiap satuan kerja Kejaksaan, khususnya di Kejari Bogor. Selain itu, adanya beberapa pegawai di Kejari Bogor yang sudah memasuki usia pensiun sebagai Pegawai Negeri Sipil (PNS), namun tidak ada pegawai yang menggantikan posisi pegawai yang sudah pensiun tersebut. Untuk mengatasi hal tersebut, Kejari Bogor sudah beberapa kali mengirimkan surat permohonan kepada Kepala Kejaksaan Tinggi Jawa Barat untuk diteruskan ke Kejaksaan Agung guna menambah pegawai di Kejari Bogor, baik itu Jaksa maupun tenaga administrasi (Tata Usaha). Sehingga untuk ke depannya, diharapkan pada penerimaan Calon Pegawai Negeri Sipil di Kejaksaan Republik Indonesia menerima banyak calon pegawai yang memiliki keahlian di bidang teknologi informasi. 
b) Kurangnya pemahaman cara menggunakan CMS

Di Kejari Bogor, masih terdapat beberapa pegawai yang kurang memahami teknologi informasi yang sudah berkembang dengan sangat pesat seperti sekarang ini. Terlebih dalam menerapkan teknologi informasi dalam mewujudkan sistem peradilan pidana terpadu seperti aplikasi CMS ini. Untuk mengatasi kendala yang demikian, Kejari Bogor telah mengirimkan pegawainya untuk mengikuti pendidikan dan pelatihan CMS pada tahun 2018 dan tahun 2019. Kemudian, Kejari Bogor juga melaksanakan Bimbingan Teknis CMS di Kejari Bogor dengan mengundang narasumber dari Pusat Data, Statistik Kriminal dan Teknologi Informasi (Daskrimti) Kejaksaan Agung pada hari Rabu tanggal 17 Juni 2020 yang memberikan bimbingan kepada Operator dan para Jaksa yang menangani perkara baik tindak pidana umum maupun tindak pidana khusus untuk melakukan input data pada aplikasi CMS.

c) Masih adanya beberapa persuratan/administrasi pada aplikasi CMS yang tidak diisi nomor surat dan belum diunggahnya berkas data penanganan perkara yang ditangani oleh Operator dan Jaksa yang menangani perkara.

Pada saat monitoring dan evaluasi pelaksanaan entry data penanganan perkara pada aplikasi CMS oleh Tim dari Pusat Daskrimti Kejaksaan Agung, ditemukan masih adanya nomor persuratan/administrasi yang tidak diisi nomor surat dan tanggal data penanganan perkara. Selain itu, masih ada data penanganan perkara yang belum diunggah ke dalam aplikasi CMS. Untuk mengatasi hal tersebut, Kepala Kejari Bogor menerbitkan Nota Dinas dan memerintahkan kepada Operator dan para Jaksa yang menangani perkara untuk melengkapi berkas persuratan/administrasi (nomor dan tanggal surat penanganan perkara pada setiap tahapan penanganan perkara) dan mengunggahnya ke dalam aplikasi CMS. 


\section{PENUTUP}

Berdasarkan uraian pembahasan hasil penelitian, maka berikut simpulan beserta saran yang dapat penulis uraikan. Pertama, penerapan CMS di Kejari Bogor merupakan salah satu bentuk upaya Kejaksaan RI mewujudkan SPPT-TI sebagai arahan kebijakan pemerintah di Kejaksaan seluruh Indonesia, dimulai dari penginputan SPDP, tahap Pra Penuntutan, tahap Penuntutan, dan tahap Eksekusi. Penerapan CMS dalam proses input data penanganan perkara tindak pidana di Kejari Bogor sudah sesuai dengan SOP dan selalu berpedoman pada Insja No. 3 Tahun 2020 sebagai dasar hukum optimalisasi pemanfaatan teknologi informasi dalam pelaksanaan tugas penegakan hukum, namun demikian SDM yang kurang memadai, kembali menjadi persoalan klasik penerapan IT di Kejaksaan. Kedua, jika dibandingkan pengadministrasian perkara secara konvensional atau manual yang sangat membutuhkan waktu cukup lama untuk menelusuri riwayat sebuah perkara, CMS lebih efektif dan efisien dan sangat membantu meringankan tugas administrasi para Jaksa di Kejari Bogor. CMS juga efektif membantu Kepala Kejari Bogor melaksanakan tugas pengawasan melekat kepada para Jaksa dan monitoring perkembangan perkara, sehingga dengan cepat dan tepat dapat segera mengambil keputusan terhadap penanganan perkara. Kejari Bogor juga memiliki peranan yang sangat penting dalam mewujudkan SPPT-TI melalui CMS, khususnya dalam hal penyajian data dan informasi kepada lembaga penegak hukum lainnya di Kota Bogor (hakim dan penyidik). Ketiga, kendala dalam penerapan CMS di Kejari Bogor diantaranya adalah kurangnya SDM yang berkompeten dan pemahaman pegawai tentang cara menggunakan CMS, serta pengadministrasian yang tidak lengkap dan belum diunggahnya berkas data penanganan perkara baik oleh Jaksa maupun operator CMS. 
Berdasarkan simpulan tersebut, maka penulis memberikan saran. Pertama, untuk menambah SDM Kejaksaan yang ahli di bidang teknologi informasi, baik melalui penerimaan pegawai baru maupun pembinaan pegawai tata usaha yang sudah ada. Kedua, Kejaksaan RI untuk melakukan inovasi lanjutan lainnya, seperti misalnya penyajian data melalui website yang tersinkronisasi dengan CMS, guna memudahkan masyarakat menelusuri perkembangan suatu perkara. Kedua, kepala Kejari Bogor rutin melakukan monitoring penginputan data CMS oleh operator dan para Jaksa, dan memberikan teguran apabila ditemukan kelalaian didalamnya. Kepala Kejari Bogor juga diharapkan dapat selalu berkordinasi dengan Pusat Daskrimti Kejaksaan Agung, untuk memvalidasi datadata yang telah di-input dan meminta dilakukan maintenance aplikasi secara rutin. 
P-ISSN: 2656-534X, E-ISSN: 2656-5358

Jurnal Suara Hukum, Vol. 3, No. 1, Maret 2021

\section{DAFTAR PUSTAKA}

\section{Buku}

Atmasasmita, R. (2010). Sistem Peradilan Pidana Kontemporer. PT. Kencana Prenada Media Group.

Cardozo, B. N. (1991). The Nature of The Judicial Process. Yale University Press.

Harahap, M. Y. (2004). Pembahasan Permasalahan dan Penerapan KUHAP, Penyidikan dan Penuntutan. PT. Sinar Grafika.

Kusumaatmadja, M. (1976). Fungsi dan Perkembangan Hukum dalam Pembangunan Nasional. Lembaga Penelitian Hukum dan Kriminologi FH Universitas Padjadjaran.

Kusumaatmadja, M. (2002). Konsep-Konsep Hukum dalam Pembangunan. PT. Alumni.

Mas, M. (2003). Pengantar Ilmu Hukum. PT. Ghalia Indonesia.

Rahardjo, S. (1980). Hukum dan Masyarakat. PT. Angkasa.

Rahardjo, S. (1983). Kamus Sosiologi. PT. Rajawali Press.

Rahardjo, S. (1991). Ilmu Hukum. PT. Citra Aditya Bakti.

Rasjidi, L. (1990). Dasar-Dasar Filsafat Hukum. PT. Angkasa.

Situmorang, M. dkk. (2009). Laporan Penelitian Hukum tentang Penyederhanaan Proses Peradilan. Puslitbang Hukum Nasional BPHN.

Syamsudin, A. (2008). Integritas Penegak Hukum; Hakim, Jaksa, Polisi dan Pengacara : Cetakan Ke-1. PT. Kompas.

Vago, S. (2016). Law and Society 10th Edition. Routledge.

\section{Artikel Jurnal}

Abdullah, S. (2014). Prinsip Efisiensi dalam Peradilan Tindak Pidana Perikanan. Jurnal Fiat Justisia, 8(3), 479.

Alkostar, A. (2002). Masalah Mafia Peradilan dan Penanggulangannya. Jurnal Hukum, $9(21), 1$.

Filgueiras, F. (2015). Transparency and Accountability: Principles and Rules For The Construction Of Publicity. Journal of Public Affairs, 16(2), 192.

Hairi, P. J. (2011). Antara Prinsip Peradilan Sederhana, Cepat dan Berbiaya Ringan dan Gagasan Pembatasan Perkara Kasasi. Jurnal Negara Hukum, Pusat Penelitian Badan Keahlian DPR RI, 2(1), 152.

Mardin, N. (2007). Makna Kepala Putusan Pengadilan: Keadilan Berdasarkan Ketuhanan Yang Maha Esa (Tinjauan Rechphilosophie). Jurnal Hukum Aktualita, II(3), 279.

Widodo, J. P. (2012). Reformasi Sistem Peradilan Pidana Dalam Rangka Penanggulangan 
Mafia Peradilan. Jurnal Dinamika Hukum, Universitas Jendral Soedirman, 12(1), 108.

\section{Website}

Kejaksaan Negeri RI. (2010). Criminal Justice System di Negara Hukum Indonesia. Https://Www.Kejaksaan.Go.Id/.

https://www.kejaksaan.go.id/unit_kejaksaan.php?idu=28\&idsu=39\&idke=0\&hal=1 $\& \mathrm{id}=1661 \& \mathrm{bc}=$,

\section{Hasil Wawancara}

Essadendra, \& Karyati. (2020). Kendala Proses Penanganan Perkara Dan Proses Input Data Penanganan Perkara Pada Aplikasi CMS.

Hutapea, H. P. (2020). Standar Operasional Prosedur (SOP) Penanganan Perkara Tindak Pidana Umum.

Saputro, H. J. (2020). Sistem Manajemen Penanganan Perkara yang Ada di dalam Aplikasi CMS.

Setiadi, R. (2020). Perkara Tindak Pidana Narkotika dan Psikotropika.

Yulianti, L. (2020). Alur Penerapan Dalam Proses Input Data Penanganan Perkara Pada Sistem Manajemen Penanganan Perkara. 